\title{
Discussion on Innovative Design based on the investigation of Culture and creative products in Hubei Provincial Museum
}

\author{
Hong Peng, Can Xiong \\ School of Art and Design, Wuhan University of Science and Technology, Wuhan, Hubei, China \\ School of Art and Design, Wuhan University of Science and Technology, Wuhan, Hubei, China \\ 395155952@qq.com, 350086508@qq.com
}

Can Xiong

Keywords: Jing-Chu culture, culture and creative products, museum

\begin{abstract}
Hubei provincial museum is a national level museum whose aesthetic features and historical and cultural values are different from that of other famous museums in ChinaThis paper mainly studies the relationship between the Jing-Chu culture and the cultural and creative products of the museum, which laid the foundation for promoting the cultural IP and the design of the culture and creative products of Hubei Provincial Museum and promoting the development of the creative cultural industry of Hubei Provincial Museum. Through literature research, combing cultural IP, field investigation, case analysis, practical participation method, summing up induction and other scientific research methods to research and analysis Hubei Provincial Museum culture and the current situation of its cultural products in different perspectives. Integrate culture and life can let people feel the charm of culture in life better.
\end{abstract}

\section{Investigation of Hubei Provincial Museum}

Hubei Provincial Museum is located next to the famous East Lake in Wuhan, Hubei Province. It is the only provincial comprehensive museum in Hubei Province, which integrates nature, history and social education. It is also one of the iconic cultural facilities in Hubei Province. In 1953, the province began to build Hubei Provincial Museum, until now Hubei Museum has become one of the national business cards. The regional culture represented by Hubei Provincial Museum is Jing-Chu culture, which has a history of more than 800 years. If the word "Jing" is added to the front, the history of the Jing-Chu culture can be traced back more than 2000 years. Although the Jing-Chu culture is a regional cultural system, it not only has spiritual culture but also includes material culture. It is ubiquitous in Jing-Chu and has a profound impact on people's lives. It is also almost all over many historical places in Hubei Province.

\subsection{Collection Culture of Hubei Provincial Museum}

Hubei Provincial Museum has a very rich cultural relics resources, with a very profound Jing-Chu history and culture. Yunxian human skull fossils, the Sword of Goujian, Bianzhong of Marquis Yi of Zeng, and Yuan Dynasty Qinghua Siai Meiping these four cultural relics are known as the four "treasure" of Hubei Provincial Museum. Whether the level of spiritual culture or material culture, it can be said that it has affected the development process of the whole Chinese culture to some extent.

\subsection{The Origin and Evolution of Jing-Chu Culture}

China has a history of thousands of years and gave birth to countless colorful cultures, among which Chu culture is a dazzling star in this long history. Chu culture originated in Jingzhou City, Hubei Province. The Chu later ruled in many areas, including the Central Plains, Wu Yue, Dongyi, Nanyue, Ba and Guizhou. It is different from the Central Plains culture who respects Confucianism. Chu culture has its distinctive characteristics. Hubei Province is the center of Jing-Chuhu culture, 
and the architecture of Hubei Museum has strong Chu culture characteristics.

\subsection{Classification of museum collections}

The Hubei Provincial Museum collections divided into eleven exhibition hall based on time and categories. They are Marquis Yi of Zeng, Chu culture, Liang Zhuangwang, Chronicle of Jiuliandun, writing history, The Art of Lacquerware in Qin and Han dynasties, the Art of Earth and Fire Ancient Porcelain, Yuanxian people, Qujia hill, Panlong city, Luminaries of Hubei During a Century.

The owner is King Junyi of the Warring States period, which has a large number, extremely high archaeological value and is well preserved. Chu Culture exhibition hall displays the Chu Culture Exhibition, which is both the name of the country and the name of the nationality at that time. Since the 1960s, more than $5000 \mathrm{Chu}$ tombs have been found in Hubei Province. Among so many Chu tombs, archaeologists have found that this is a good reflection of the living conditions of Chu people at that time. The tomb of Liangzhuang king is a joint tomb, which leaves many valuable cultural relics, among which the gold ingots from the West at that time witnessed Zheng He's great feat of sailing to the West. The Chu Tomb of the warring states period was unearthed in Zaoyang City, Hubei Province. It was buried by the aristocrats of the former Chu State and was the largest and most well-preserved Chu tomb found in our country at present .

The Writing History exhibition hall shows Bamboo slips in the Warring States period, Qin, and Han dynasties. Hubei is one of the most unearthed provinces of the Bamboo slips . The lacquer ware technology in China was first used in the Neolithic period, among which the lacquerware unearthed in Hubei Province can best represent the Qin and Han lacquerware. Lacquer Art in Qin and Han dynasties is a photo exhibition that displays lacquer art during that period . The Art of Earth and Fire Ancient Porcelain exhibition is mainly based on porcelain in Hubei before and after Yuan Dynasty, showing the development of porcelain in this period

Qu Jialing culture is a kind of stone culture, which fully shows the life face of the prehistoric clan in Jianghan area and has great archaeological value. It is the same as Erligang's upper culture. Luminaries of Hubei During a Century showed more than 100 heroes coming out of Jing-Chu. The deeds of these heroes are shown in many forms, such as cultural relics, pictures and so on.

\section{Analysis of the present situation of Cultural creation products in Hubei Provincial Museum and the Cultural creation products of Beijing Palace Museum}

At present, the product design of the culture and creative products in the Hubei Provincial Museum is still in the primary stage. The design idea is limited. The product variety is single. The identification is not strong, and the target population is not clear.

\subsection{The Analysis of the Current Situation of the Arts and Creative Products in the Hubei Provincial Museum}

After sorting out all the cultural and creative products in Hubei Provincial Museum, they are divided into four different types, namely, Culture and Creative Commodity Store, APP, Public Education Service, and performance. (Table 2.1). Table 2.1 summarizes the advantages and disadvantages of current designs. Hubei Provincial Museum culture and creative products are divided into two categories, cultural and creative products, and traditional imitation classics. Table 2.2. Table 2.3 is the classification and arrangement of the culture and creative products in the Museum of the North and the North. 
Table 2.1 Manage types of culture and creative products in Hubei Provincial Museum

\begin{tabular}{|c|c|c|}
\hline Types & Advantages & Disadvantages \\
\hline $\begin{array}{c}\text { Cultural and Creative } \\
\text { Commodity Store }\end{array}$ & $\begin{array}{c}\text { Put all the cultural and creative } \\
\text { products together to facilitate } \\
\text { tourists to understand and buy. }\end{array}$ & $\begin{array}{c}\text { The layout of the products in the } \\
\text { store is not neat and the products } \\
\text { are not representative. There is no } \\
\text { systematic classification. }\end{array}$ \\
\hline APP & $\begin{array}{c}\text { It is convenient for tourists to } \\
\text { understand the museum products on } \\
\text { their mobile phones and enrich the } \\
\text { interactive experience. }\end{array}$ & $\begin{array}{c}\text { Insufficient publicity, software } \\
\text { stability, and perfection need to be } \\
\text { improved. }\end{array}$ \\
\hline Public education & $\begin{array}{c}\text { Both old and young are suitable, } \\
\text { which not only enriches the } \\
\text { experience fun of visitors but also } \\
\text { has the significance of education } \\
\text { and publicity. }\end{array}$ & $\begin{array}{c}\text { The area of the event is not } \\
\text { connected, and the audience is not } \\
\text { large. }\end{array}$ \\
\hline Performance & $\begin{array}{c}\text { The ritual and music system is the } \\
\text { foundation of Chinese traditional } \\
\text { culture, and the bell is the } \\
\text { characteristic of Hubei Province, } \\
\text { which has created the key cultural } \\
\text { creative brand. }\end{array}$ & $\begin{array}{c}\text { The visual guide system in the } \\
\text { library needs to be improved. }\end{array}$ \\
\hline
\end{tabular}

Table 2.2 Collation of cultural and creative products in Hubei Provincial Museum

\begin{tabular}{|c|c|c|}
\hline $\begin{array}{l}\text { Cultural and creative } \\
\text { products }\end{array}$ & Culture factor & Product Example (Picture) \\
\hline Gold wire pendant & Marquis Yi of Zeng & \\
\hline Bookmark set & $\begin{array}{c}\text { Yuan Dynasty Qinghua Siai } \\
\text { Meiping }\end{array}$ & \\
\hline Ashtray & The sword of Goujian & \\
\hline Folding fan & Yunmeng Qin bamboo slips & \\
\hline
\end{tabular}


Table 2.3 collation of traditional imitation classics in Hubei Provincial Museums

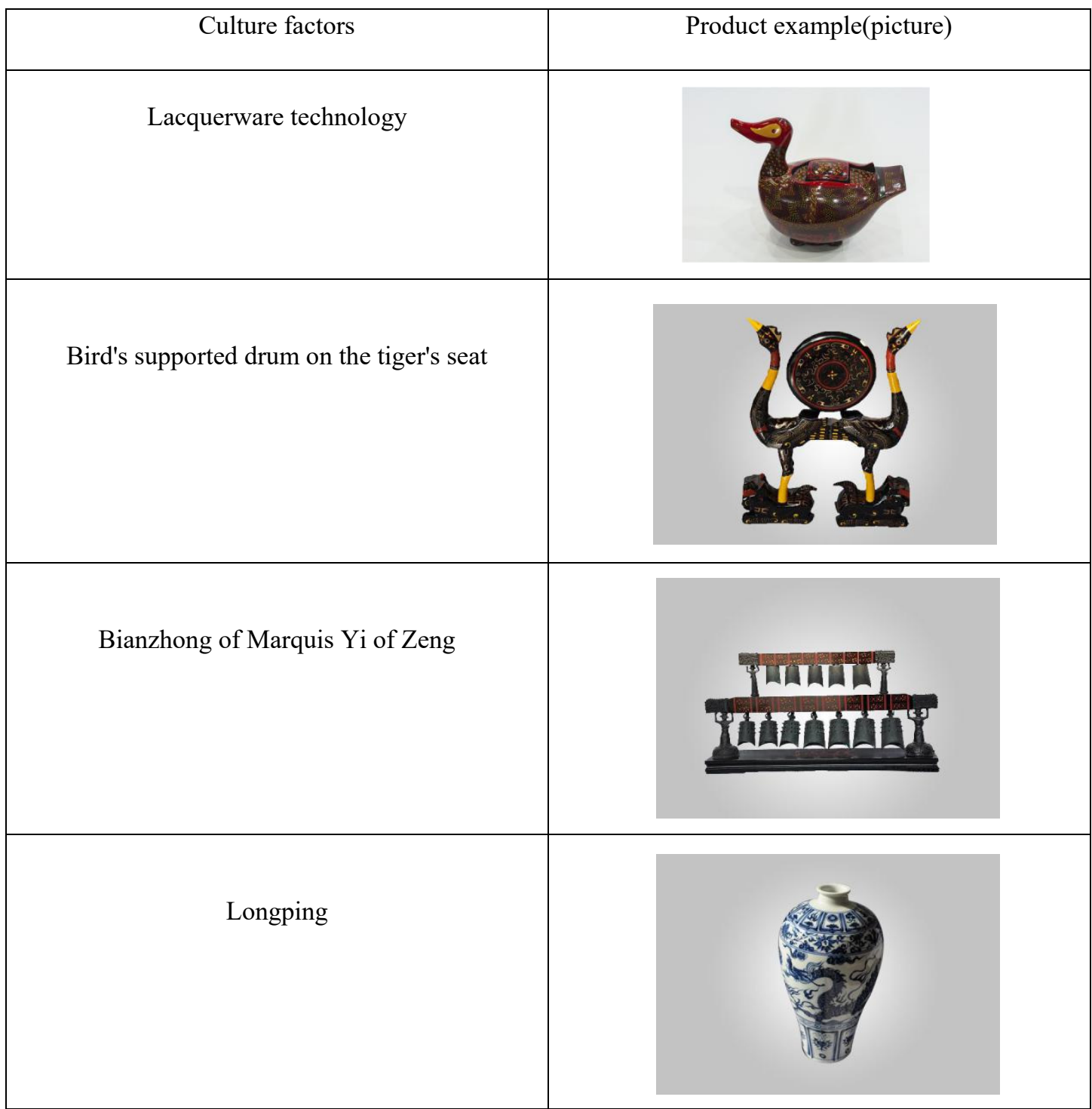

The Hubei Provincial Museum brings together the broad and profound history and culture of Jing-Chu. At present, shops are specializing in cultural and creative products in Hubei Provincial Museum. Product design and development also began to attach importance to and strive to do a good job. The store is equipped with special personnel to serve and explain.

At present, cultural and creative products have no integrity and series, lack of star products, and leading products without emphasis. And a lot of products in the museum are highly copied. There is no too much innovation in modeling; the form of expression is also relatively single, but also lack story. There is no bright product in front of consumers. Many cultural and creative products designs are bookmarks, cups, pillows, and so on, which do not highlight the characteristics of Jing-Chu culture and are not highly identifiable.

\subsection{Analysis of Cultural creation products of Beijing Palace Museum}

Beijing Palace Museum, located in the Forbidden City of Beijing, can be one of the best comprehensive museums in China, and it is also the largest museum of ancient culture and art in China. The Beijing Imperial Palace Museum, like the Taipei Palace Museum, is a leader in the field of literary creation in museums in China. In 2016, the Palace Museum, with its unique IP image design and development, led the national museum to enter the upsurge of culture and creative products development. On May 11,2016, the Ministry of Culture, the State Development and Reform Commission, the Ministry of Finance and the State Administration of Cultural Relics have 
published the Some opinions on promoting the Development of Cultural and Creative products in Cultural and Cultural relics Units which put in place a new step in the development of the museum's cultural and creative development. With the progress of all museums, all museums begin to design and develop their cultural IP.

The characteristics of the products of the Palace Museum are now classified and sorted out, as shown in Table 2.4.

Table 2.4 Special Classification and arrangement of cultural and creative products in the Palace Museum

\begin{tabular}{|c|c|c|}
\hline Royal element & Product example (name) & Product example(picture) \\
\hline Palace figure & $\begin{array}{l}\text { [The fourth prince and little } \\
\text { princess] head-shacking dolls }\end{array}$ & 9 \\
\hline Palace cloth & [court dress] cell phone shell & \\
\hline Palace building & $\begin{array}{c}\text { [Dragon kiss of the Palace] Art } \\
\text { ruler }\end{array}$ & \\
\hline Royal supplies & $\begin{array}{c}\text { [double-dragon playing ball, } \\
\text { sacred purpose and symbol } \\
\text { card] luggage tag }\end{array}$ & \\
\hline the emperor's words & $\begin{array}{l}\text { [the whisper in the court] tape } \\
\text { seal }\end{array}$ & \\
\hline royal jelly & $\begin{array}{l}\text { [Zhuangzhuang and } \\
\text { meimei ]Metal buckle note }\end{array}$ & \\
\hline
\end{tabular}

The cultural products of the Beijing Palace Museum are the historical and cultural stories and the details of the Forbidden City itself. It created their own IP culture. Not only this but also their own Palace Museum flagship store and online sales are very excellent. So cultural creativity is not simple splicing of IP elements. Now is the information age, so to promote the development of museum creation must also use the Internet.

Hubei Provincial Museum wants to learn this kind of cultural creation development model and make Jing-Chu culture unique in our country. The Hubei Provincial Museum will develop a series of cultural and creative products with different story background so that the product "live again," which also adds a lot of interest. Consumers are also more eager to buy. 


\section{The Innovative Design Path of the culture and creative Product in the Hubei Provincial Museum}

\subsection{The Analysis of the IP Image of the Hubei Provincial Museum Based on the Factor Extraction}

The factor extraction method is to extract the color extracted by design software through the model of cultural factor extraction, which combines the analysis of visual morphological characteristics with the analysis of the characteristics of Jing-Chu culture represented by Hubei Provincial Museum. The cultural factors, including the shape features, can be collected in the database of characteristic factors in the collection. The extraction method of these factors can better show Jing-Chu culture in the design of cultural and creative products.

Based on the analysis of the human skull fossils of Baoyun County, the Sword of Goujian, Bianzhong of Marquis Yi of Zeng, and Yuan Dynasty Qinghua Siai Meiping in Hubei Museum. Then outline of the outer outline by 2D software (PS). The characteristics of the four cultural relics can be extracted, and the main color analysis can be used to obtain the cultural factors that can be designed. See Table 3.1 for the analysis chart of materials of Hubei Provincial Museum and Table 3.2 for the main colors of Hubei Provincial Museum.

Table 3.1 Analysis Map of Treasure Morphology in Hubei Provincial Museum

\begin{tabular}{|l|l|l|l|l|}
\hline $\begin{array}{c}\text { Museum" in the Hubei } \\
\text { Provincial Museum }\end{array}$ & & & & \\
\hline $\begin{array}{c}\text { Feature line morphology } \\
\text { extraction }\end{array}$ & & & & \\
\hline
\end{tabular}

Table 3.2 Color Analysis Map of four treasure in the Hubei Provincial Museum

\begin{tabular}{|c|c|c|c|c|}
\hline "Four treasure of the \\
Museum" in the Hubei \\
Provincial Museum
\end{tabular}




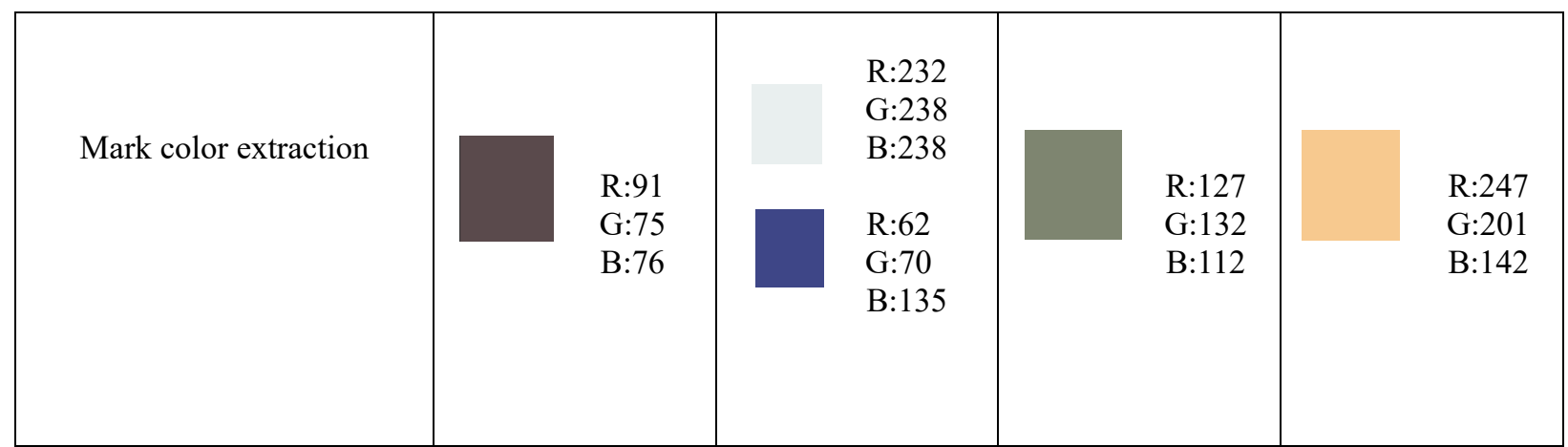

The treasure of the Hubei Provincial Museum is the Sword of Goujian, so it should be developed around this key IP. At the same time, the museum will also launch different special exhibitions every year, carry out IP publicity, and use this IP culture to promote the development of the whole museum. Sword is a masculine thing which can defend oneself to kill the enemy without losing majesty. The tie designed with the shape and pattern of the Sword of Goujian means that it is as indispensable for men to wear ties as ancients wear swords when they travel to the workplace. Full with Jing-Chu culture tie is not only beautiful and generous but also give people a sense of elegance and solemnity.

Based on integrating Jing-Chu cultural elements in modeling design, it is necessary to reflect the fashion sense of modern design. This will bring people a sense of visual harmony.

If a good product uses good color, it will attract the attention of consumers for the first time, and can better stimulate consumers' desire to buy. In ancient time, Chu people prefer red color and regard red as precious. Many lacquer ware also uses the color match of black bottom and red color. The red color matching and Han embroidery techniques are used to design the patterns on the sword of Goujian, the king of Yue. Red has the characteristics of enthusiasm and vivacity, which will increase the vitality of the product and can effectively distinguish it from the traditional tie color. As a result, it is neither fashionable nor public.

Art comes from life", combining function and form can develop a series of life supplies. To let consumers enjoy art, but also have the feeling of returning to life. In the design, to regard culture and creative products as a part of life, we must start from the bit by bit of life and look for problems in life. Since it comes from life, many of them are stationery and pillows, and some museums design a lot of jewelry. Few men are specially designed for men. Now many men wear formal clothes, and ties at work, which can be redesigned on the basis of the appearance of the Sword Goujian and the pattern of its sword body can be extracted.

Hubei Provincial Museum is a national first-class museum. Based on the orientation of this first-class museum, the designed and developed culture and creative products can be used as a gift to foreign leaders when they visit China and can fully reflect the extensive and profound culture of China. Export culture and become an ambassador for Chinese and foreign culture communication.

\subsection{The relationship between Museum Positioning and culture and creative products}

Hubei Museum is a national first-class museum. There is an evaluation criterion for the national first-class museum. Since 2008, China has implemented the evaluation of museums at the national level, and by July 2016, the latest Museum grading Evaluation methods of Museum and Museum Grading Evaluation Criteria have been revised. Its main purpose is to standardize the management of museum industry further, promote the improvement of service standards, improve the quality level, improve the quality evaluation system with display education and open service as the core, and promote the all-round development of museum cause. The evaluation criteria include three aspects: integrated management and infrastructure; collection management and scientific research; exhibition and social services; and museums at the national level if they meet the evaluation criteria. Lacquerware and bronze ware are the representatives of Jing-Chu cultural relics. Therefore, the 
patterns of these two elements have been restructured in many cultural and creative products of Hubei Provincial Museum and used in the design. At present, many museums in China have many kinds of competition. The museum is facing the competition, as well as the financial problems brought about by the museum itself in the process of operation, as well as with the improvement of people's living standards. It is not just content to go into the museum for a physical visit. If the museum is limited to the form of physical exhibition, then it also limits the breadth and depth of the development of museum collection culture. In this paper, three first-class museums in Hubei Province are compared with each other (see Table 3.3).

Table3.3 Design of the Relationship between the Classification and the Cultural and Creative Products (in comparison with the three-level museums in Hubei Province)

\begin{tabular}{|c|c|c|c|c|c|}
\hline $\begin{array}{l}\text { Name of the } \\
\text { museum }\end{array}$ & IP image & Level & Current product category & $\begin{array}{c}\text { Planned product } \\
\text { category (product) }\end{array}$ & Material \\
\hline $\begin{array}{c}\text { Hubei Provincial } \\
\text { Museum }\end{array}$ & $\begin{array}{l}\text { Yunxian human skull } \\
\text { fossil, the Sword of } \\
\text { Goujian, Bianzhong of } \\
\text { Marquis Yi of Zeng, } \\
\text { Yuan Dynasty Qinghua } \\
\text { Siai Meiping }\end{array}$ & First class & $\begin{array}{c}\text { Cultural relics retouches, } \\
\text { books, bookmarks, canvas } \\
\text { bags, cell phone buckle, } \\
\text { jewelry, lamps, lacquer } \\
\text { plates }\end{array}$ & Water bottle & $\begin{array}{c}\text { Water cups can be made of } \\
\text { nano-ceramic materials }\end{array}$ \\
\hline $\begin{array}{l}\text { Museum of } \\
\text { Wuahn }\end{array}$ & $\begin{array}{c}\text { Qing dynasty Qianlong } \\
\text { model white jade } \\
\text { double Phoenix neck } \\
\text { pot, Shang dynasty, } \\
\text { animal face grain cross } \\
\text { hole urn, the three } \\
\text { Kingdoms Wu celadon } \\
\text { dock castle }\end{array}$ & First class & $\begin{array}{c}\text { Cultural relics engraved, } \\
\text { books, notes }\end{array}$ & $\begin{array}{l}\text { Home used } \\
\text { embroidery } \\
\text { (backpack, wallet, } \\
\text { neck pillow) }\end{array}$ & $\begin{array}{c}\text { Combine the craftsmanship } \\
\text { and materials of Han } \\
\text { embroidery }\end{array}$ \\
\hline $\begin{array}{l}\text { Museum of } \\
\text { Jingzhou }\end{array}$ & $\begin{array}{c}\text { Tiger bird rack drum, a } \\
\text { pair of Phoenix ear cup, } \\
\text { stone Yue, bronze } \\
\text { tripod }\end{array}$ & First class & $\begin{array}{l}\text { Cultural relics engraving, } \\
\text { books, silk goods }\end{array}$ & Silver jewelery & $\begin{array}{l}\text { Match blue and green with } \\
\text { turquoise with silver }\end{array}$ \\
\hline
\end{tabular}

\section{Conclusion}

Through this investigation and innovation path exploration, this paper combs the new path of cultural creation product development of Hubei Provincial Museum constructed by IP, which is three first-class collections. The cultural factor extraction method is used to sort out the cultural elements of the museum and the established factor library is scientific and reasonable, which provides convenience for the vast number of literary creation design work and enhances the openness of the museum collection to the outside world. To enhance consumers' cultural self-confidence and cultural identity, but also to push the content and form of Hubei Provincial Museum culture and creative product development to a new level and height.

Now is the age of science and technology information, many products also use some high-tech materials, such as some nanometers and carbon fibers and so on. The use of these materials can make the product more valuable for purchase and collection. Combined with Jing-Chu culture to promote. Science and technology are becoming more and more developed. In order to highlight the characteristics of Jingchu culture, this time we are going to use Hubei traditional Han embroidery as the design material of tie. Han embroidery is based on Chu embroidery, which combines the advantages of the north and south embroidery methods. A new embroidery method with distinctive local characteristics has been combined. Han embroidery is a national intangible cultural heritage. The use of Han embroidery techniques and materials, will make the product appear special and exquisite and very regional. 


\section{References}

[1] Feng Tianyu, he Xiaoming, Zhou Jiming. History of Chinese culture [M]. Shanghai: Shanghai people's Publishing House, 1990. P

[2] Song Rui. A study of Jingchu Culture under the background of Chinese Culture self-confidence [J]. Popular Literature and Art,2018.

[3] Chen Shaohui. The recommendation in Jingchu culture inherits and innovate [J]. Study Weekly,2018.

[4] Yang Huang. A study on the development strategy of cultural derivatives in local museums [J]. Cultural relics, Spring and Autumn,2010.

[5] Yang Jing. Design, research, and development of museum souvenirs [J]. Packaging engineering, 2011.

[6] Chen Jinshuan. The spiritual connotation of Chu culture and its application of typical elements [J]. Journal of Wuhan Textile University,2018.

[7] Zhang Wei. A study on the mode of creation and development in the public cultural service of the museum[D]. Wuhan University of Science and Technology, 18.

[8] Niu Xue, Liu Fen. The Activation and Application of Museum Cultural relics Resources in Hubei Province: a study on the Design of Chu Culture Cultural creation products [J]. Science and Education Exchange (first ten days), 2018 (03): 179 / 180.

[9] Qian Hong. A brief analysis of the social education service function of the museum literary creation industry in Hubei Province [J]. Museum Development, 2017 (00): 86 / 93.

[10] Song Zongfeng, Chen Jianjun, Lin Liguang, Zhu Zengqing, Liu Guoliang. Topological optimization design of stochastic interval model based on interval factor method [J]. Journal of Applied Mechanics,2009, 26 (02): 243247404.

[11] Zhang Zixin.The practice of museum literary creation-the development and thinking of the first Bo Wenchuang [J]. The Capital Museum,2013 (00)

[12] Jiang Han.Practice and thinking on the development of Culture and creative products in the Suzhou Museum [N]. Chinese Heritage News, 2014 (005)

[13] Li Feng, Hu Xuwen.Observation and reflection on ecological and cultural products of museum stores [N]. Chinese Heritage News, 2013 (005) 